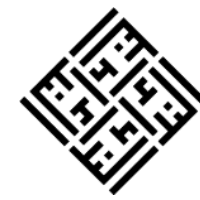

Anida (Aktualisasi Nuansa Ilmu Dakwah)

Volume 20, Nomor 2, 2020, 201-220

https://doi.org/10.15575/anida.v20i2.10820

Fakultas Dakwah dan Komunikasi, UIN Sunan Gunung Djati Bandung

https://journal. uinsgd.ac.id/index.php/anida

\title{
Dakwah Da'i Nahdlatul Ulama dalam Mencegah Penyebaran Covid-19
}

\author{
Moh. Lukman Hakim ${ }^{1}$, Moh. Ali Aziz ${ }^{2}$ \\ 1,2 Komunikasi dan Penyiaran Islam, UIN Sunan Ampel, Surabaya \\ Email:loecmanbro@gmail.com \\ Email:malzis@yahoo.com
}

\begin{abstract}
ABSTRAK
Mewabahnya Covid-19 sebagai pandemi global perlu menjadi perhatian serius, khususnya bagi para da'i sebagai figur dan panutan publik bagi masyarakat. Artikel ini bertujuan untuk mengetahui bagaimana tokoh da’i Nahdlatul Ulama diantaranya adalah Gus Mus, Gus Miftah dan Gus Baha memberikan nasehat dan arahan tentang pencegahan Covid-19 agar dapat menjadi bahan edukasi masyarakat melalui dakwah mereka di Youtube. Menggunakan pendekatan kualitatif dengan metode analisis pesan, kajian ini menemukan bahwa para da’i tersebut berpesan untuk selalu mengutamakan keimanan terhadap Allah sebelum rasa khawatir akan Covid-19 serta bagaiamana Islam menjadikan kemudahan tersendiri sebab keterbatasan kondisi yang diakibatkan oleh pandemi ini, khususnya pada beberapa ritual ibadah. Implikasi penelitian ini sebagai upaya mencegah penyebaran Covid-19 dalam perspektif dakwah di antara masyarakat.
\end{abstract}

Kata Kunci: Da’i, Nahdlatul Ulama, Covid-19

\section{ABSTRACT}

The outbreak of Covid-19 as a global pandemic needs serious attention, especially for da'i as public figures and role models for society. This article aims to know how the da'i of Nabdlatul Ulama, including Gus Mus, Gus Miftah, and Gus Baba, provide advice and direction on the prevention of Covid-19 so that it can be used as material for public education through their da'wah on Youtube. Using a qualitative approach with the message analysis method, this study finds that the da'i are advised to always prioritize faith in Allab before worrying about Covid-19 and how Islam makes its own convenience due to the limited conditions caused by this pandemic, especially in some rituals. worship. The implication of this research is to prevent the spread of Covid-19 from the perspective of da'wah among the community.

Keywords : Da'i, Nabdlatul Ulama, Covid-19 


\section{PENDAHULUAN}

Sepanjang tahun 2020, masyarakat dunia, khususnya Indonesia dibuat panik oleh wabah berupa penyakit menular yang mengakibatkan gangguan pernafasan bernama Coronavirus disease-2019, yang kemudian dikenal dengan Covid-19. Virus ini menyebar dan menginfeksi saluran pernafasan manusia, ditandai dengan suhu tinggi mencapai $38^{\circ} \mathrm{C}$, sesak nafas, batuk, hingga kemungkinan terburuk mencapai kematian. proses penyebaran virus ini sangatlah cepat sampai menjadikannya global pandemic. Virus ini pertama kali terdeteksi di Wuhan China, yang kemudian secara resmi di Indonesia juga dinyatakan ada masyarakat yang positif terjangkit pada awal Maret 2020 (Ihsanuddin 2020). Pandemi ini menjadi musibah yang menakutkan bagi umat manusia. Musibah ini juga berdampak pada banyak segmen keseharian masyarakat yang bersifat interaksi sosial secara langsung. Sebagai upaya pencegahan, kehidupan manusia sebagai makhluk sosial harus dibatasi sebagai dengan diberlakukannya social distancing. Mulai dari pekerjaan sehari-hari, kegiatan pariwisata, kegiatan pendidikan, hingga kegiatan peribadatan yang bersifat jama'ah, meski berat karena harus keluar dari kodrat manusia sebagai makhluk sosial, hal tersebut harus dilakukan agar para masyarakat selamat dan terhindar dari penyebaran Covid-19. Wabah yang mendunia ini menjadikan pemerintah, para dokter, tokoh publik dan semua pihak yang terkait berupaya untuk bersama ambil bagian mencegah dan mengatasi penyebaran virus ini, termasuk didalamnya para da'i sebagai tokoh spiritual bagi masyarakat (Aji: 2020, 396).

Keputusan pemberlakuan social distancing dalam skala nasional (di Indonesia) kemudian berdampak pada banyak sektor kehidupan, salah satu dampak yang terasa adalah pembatasan kegiatan keagamaan yang bersifat kerumunan (baca: jama'ah) seperti shalat jamaah di masjid-masjid, kegiatan kajian, tabligh akbar dan sejenisnya, dari sini tampak bahwa sektor dakwah juga mendapat pengaruh yang cukup besar akibat pandemi ini.

Pembatasan kegiatan peribadatan yang bersifat jama'ah diberlakukan oleh pemerintah dalam rangka memutus rantai penyebaran Covid-19 dalam lingkungan ibadah. Keputusan ini tidak menjadikan para da'i untuk patah semangat dan berhenti dalam mensyiarkan agama Islam, namun sebaliknya menjadi tantangan dan bentuk dakwah itu sendiri bahwa keimanan harus tetap dilandasi dengan ikhtiar. Dalam melanjutkan estafet dakwah, para da'i harus tetap berpijak pada satu keimanan bahwa tidak ada satupun peristiwa yang terjadi di dunia ini -bahkan menyebarnya virus Covid-19 ini tanpa kehendak dan kuasa Allah SWT (Juhari: 2020, 48). Karenanya, dalam proses menjalankan dakwah semua hal tetap harus dimuarakan pada Tuhan Yang Maha Esa, tidak ada tempat berlindung dan berserah diri kecuali kepada Allah SWT yang Maha Kuasa atas segala hal di dunia ini. 
Proses dakwah secara ideal biasanya berlangsung normal dan terkondisikan dengan baik, namun akibat wabah yang 'membatasi' pergerakan manusia ini, para da'i mulai tidak bisa melakukan aktivitas dakwahnya secara normal, mereka tidak boleh berinteraksi langsung dengan audien dan menjaga jarak sesuai protokol kesehatan yang dianjurkan pemerintah. Sehingga saat Pembatasan Sosial Berskala Besar (PSBB) diterapkan, jangkauna para da’i mulai terbatas dan tidak bisa pergi keluar kota untuk mensyiarkan dakwahnya. Semua fenomena ini menggambarkan bahwa proses dakwah mengalami gangguan yang menyebabkan bermacam kendala dalam proses penyampaian dan pelaksanaannya. Sesungguhnya dalam setiap proses dakwah selalu akan terdapat tantangan dan cobaan didalamnya, entah itu dari internal da'i sendiri atau eksternal lingkungan dan sekitarnya. Oleh karenanya, dibutuhkan keahlian dan kreatifitas da'i dalam menyikapi semua fenomena dan tantangan ini sehingga proses dakwah dapat terus berlangsung dan tidak mengalami fase stagnansi.

Di dalam Al-Quran, Allah berfirman untuk saling tolong menolong dalam kebaikan dan takwa, seruan tersebut tertuang dalam QS. Al-Maidah ayat 2, hal ini dapat diartikan bahwa muslimin harus saling membantu satu sama lain, utamanya ketika dalam masa sulit seperti saat ini, Covid-19 berdampak banyak pada pekerjaan dan penghasilan masyarakat, mulai yang tiba-tiba pemasukan untuk kebutuhan keluarga harus terhenti karena di PHK, para ojek online yang tidak bisa beroperasi karena kebijakan social distancing dan lain semacamnya. Selain sisi materi, tentunya musibah ini juga berdampak pada psikologi para masyarakat terdampak wabah ini, hal ini bisa saja menjadikan mereka bertindak diluar batas kebiasaanya. Dalam Islam kita dianjurkan untuk saling membantu, disinilah salah satu peran da'i untuk menyerukan kewajiban kaum muslimin terhadap lingkungannya, di sisi lain juga para dai juga memiliki peran untuk terus mengajak para masyarakat pada ketauhidan atas Allah SWT. (Fahrurrozi: 2017, 5) agar tidak terjerumus dalam kebathilan akibat psikologis yang tertekan setelah terdampak Covid-19 ini. dalam ketentuannya, dakwah dalam Al-Quran dijelaskan dengan 3 cara utama, yakni bil-Hikmah dimana para da'i memposisikan diri mereka sebagai uswatun hasanah bagi mad'u dan lingkungannya baik melalui isyarat atau perilaku kesehariannya. Selanjutnya bil-Mau'idatil Hasanah, yakni da'i memberikan penjelasan dan arahan verbal seperti melalui ceramah, khutbah, nasehat dan sebagainya agar hati para mad'u tetap tenang dan berada dalam jalan kebaikan Allah. Lalu yang terakhir adalah bil-mujadil billati hiya ahsan, pada tahap ini adalah jika mad'u memang benar-benar kontra dengan penjelasan dakwah da'i, maka boleh dibantah dengan diskusi atau berdebat (secara baik) agar mad'u sadar dan tidak lagi menolak seruan tersebut (Al Bayanuni: 1995, 205). 
Sejatinya, kegiatan dakwah bukanlah semata hanya bentuk tanggung jawab dan kesadaran seorang pemeluk Islam terhadap agamanya, namun lebih dalam lagi pada konsekuensi dia sebagai hamba Allah yang paham terhadap perintahNya dan Rasul-Nya yang tertuang dalam ayat-ayat suci Al-Quran dan hadist-hadist (Nurhuda and Al-Farisi: 2020, 128). Kegiatan ini merupakan salah satu proses penting dalam agama Islam, sebab senyatanya intensitas penyebutan kedua sumber tersebut tentang dakwah relatif sering, baik mulai pemahaman dakwah itu sendiri, metode, tujuan, materi, media, hingga tantangan dakwah itu sendiri. Sedemikian pentingnya tugas dakwah ini sebagai kewajiban seorang muslim terhadap agamanya, agar proses keagamaan tetap berlangsung baik dan benar sesuai bagaimana Allah memerintahkannya melalui Nabi Muhammad dahulu kala. Untuk memahami dakwah dengan benar, seorang da'i harus benarbenar pokok kembali pada Al-Quran dan hadist Nabi sebagai dasar utamanya, upaya ini agar 'keorisinilan' dakwah itu sendiri tetap terjaga dan tidak keluar dari garis-garis ketentuan Allah SWT. (Al-Qahthani n.d. 531)

Pada masa dimana banyak timbul masalah-masalah kontemporer seperti saat ini, keberadaan seorang da'i atau ulama sebagai sosok yang berperan sebagai panutan bagi masyarakat, sangat dibutuhkan dan dituntut untuk mengambil tangan dalam mengatasi berbagai macam permasalah yang terjadi dan semakin beraneka ragam setiap saat (Fahrurrozi: 2017, 4). Tanpa keberadaan dai sebagai problem solver, maka kehidupan sosial masyarakat bisa saja tidak tertata dengan baik dan sesuai dengan ajaran Islam yang seharusnya rahmatan lil 'alamiin.

Selain tugas di atas, keberadaan dai pada posisi tertentu dapat di jadikan sebagai elemen pemerintah non formal oleh masyarakat dimana mereka menjadi tempat 'berdiskusi' menyelesaikan masalah keseharian masyarakat baik konflik, kerohaniaan, kesadaran beragama dan sejenisnya. Jadi disini, seorang da'i tentu dituntut untuk memiliki kepribadian yang baik secara jasmani dan rohani sehingga masyarakat mampu benar-benar ta'dzim dan mengikuti da'i tersebut dalam mencari solusi suatu masalah tertentu, termasuk juga didalamnya masalah Covid-19 yang saat ini berakibat pada banyak sektor keseharian masyarakat. Tentu masyarakat membutuhkan sosok da'i yang mampu membimbing mereka pada jalan keluar dari problematika yang diakibatkan Covid-19 ini, baik secara material maupun psikologis masyarakat tersebut agar tidak begitu saja menyerah dan kehilangan harapan untuk terus melanjutkaan kehidupannya (Hajar, S.N.D., 3) Pada beberapa kasus tertentu juga seorang da'i dapat menjadi acuan pemerintahan dalam memutuskan suatu kebijakan yang akan diberlakukan pada masyakarat, hal tersebut diakibatkan karakter da'i yang memang benar-benar banyak mengetahui bagaimana kondisi masyarakat dilapangan sebab interaksi dan hubungannya yang teramat dekat dengan masyarakat itu sendiri. 
Nahdlatul Ulama atau biasa dikenal sebagai NU adalah salah satu organisasi Islam senior terbesar di Indonesia, kiprahnya dalah dunia dakwah sudah menyentuh pada banyak sektor. Organisasi yang dirintis oleh KH. Hasyim Asy'ari pada tahun 1926 silam ini merupakan organasasi Islam berideologi ablus sunnah wal jama'ah atau dikenal dengan Aswaja (Muhaemin: 2013, 315). Sistem kaderisasi atau regenerasi ulama-ulama dan tokoh keagamaan NU sangatlah runtut dan berangsur antar generasi. Beberapa tahun belakangan ini da'i-da'i muda NU semakin banyak dikenal oleh masyarakat, selain karena kadar keilmuannya yang memang dalam, perkembangan teknologi juga menjadi salah satu faktor pendukung semakin luasnya syiar dakwah da'i-da’i tersebut. Pada penelitian ini, penulis membatasi tokoh NU sebagai objek da'i yang akan dikaji pada 3 orang yakni Gus Mus, Gus Miftah dan Gus Baha agar fokus lebih terarah dan hasil yang diharapkan pada tulisan ini benar-benar sesuai dengan fokus yang ditentukan.

Dalam kurun waktu 2-3 tahun belakangan ini, ulama dan da’i muda NU mulai banyak 'tumbuh', dikenal dan mengambil peran dikalangan masyarakat sebagai sosok yang tabligh, yakni menyampaikan dan mengajarkan tentang keislaman pada masyarakat. Pada bahasan peran da'i dalam mencegah penyebaran Covid-19 pada kajian ini, penulis akan membatasi

Pasca diberkalukannya social distancing dan pembatasan kegiatan yang melibatkan kerumunan dan kontak fisik secara langsung antar masyakarat akibat Covid-19, kegiatan dakwah juga merasakan dampak dari fenomena ini, sehingga laju dakwah mengalami hambatan karena para da'i tidak lagi bisa melakukan safari dakwah dan jama'ah juga tidak boleh mengadakan kegiatan yang berkerumunan. Disamping hal ini, kegiatan dakwah juga harus tetap berjalan dan tidak boleh sampai terhenti, terutama dengan hadirnya problem Covid-19 di masyarakat ini sebagai suatu masalah baru, dalam konteks ini da'i harus mengambil peran untuk bersama-sama memecahkan masalah ini (Munir, Fauzi, and Putra 2020, 140).

Perkembangan media dan internet dimasa kini rasanya sangat sesuai jika dijadikan salah satu jalan keluar agar proses dakwah tetap berlangsung dikalangan masyarakat, dimana kontak fisik dibatasi dan masyarakatpun mulai baramairamai melek teknologi dan menggeser banyak kebutuhan mereka pada dunia online atau internet. Meski sebelum Covid-19 kasus dakwah online ini sudah dilakukan beberapa da'i, tapi secara khusus hal ini juga tetap menjadi masalah baru karena kemasifan penggunaan media meningkat drastis akibat Covid-19 ini, semua sektor juga beralih menggunakan media daring untuk melakukan interaksi sosial dan menjalankan kegiatan harian.

Salah satu platform online yang interaksi penggunanya meningkat drastis 
sejak pandemi merebak adalah Youtube, platform ini menyajikan layanan berbagi video, bentuk fungsi dari situs ini adalah untuk mengunggah video yang dapat kita bagikan secara online ke khalayak di internet baik secara delay maupun live streaming yang memberikan fitur komentar dan menjadikannya berbeda dari televisi. Flatform ini sendiri memiliki lebih dari 1 milliar pengguna dan masih terus meningkat secara keseluruhan telah menjangkau lebih banyak pemirsa di rentang usia 18-49 tahun daripada media sosial manapun di dunia (Faiqah: 2016, 260).

Pasca fenomena pandemi tersebut, tentunya para da’i juga harus menyesuaikan dan berkembang dalam aspek digital sehingga proses dakwah tetap berlangsung. Sehingga para da'i tetap mampu menjangkau mad'unya dan memberikan nasehat dan pemecah masalah ditengah mewabahnya Covid-19 ini, terutama dalam hal pencegahan dan penanganan Covid-19 itu sendiri baik secara jasmani maupun rohani keagamaan.

Sesuai pembahasan di atas, penelitian ini bermaksud untuk menganalisis pesan-pesan dakwah yang disampaikan oleh Gus Mus, Gus Miftah dan Gus Baha tentang Covid-19 yang disampaikan melalui video da'i-da'i tersebut yang ada di Youtube, tujuannya adalah untuk memahami isi pesan-pesan dakwah para da'i tersebut khususnya sebagai 'obat' rohani bagi masyarakat yang saat ini tengah dilanda wabah pandemi Covid-19.

Selanjutnya, sebagai rujukan kebaruan dalam penelitian ini, maka penulis akan memaparkan beberapa peneltian terdahulu yang berkaitan dengan penelitian ini, antara lain: Penelitian yang dilakukan M. Ikhsan Ghozali (2017) tentang peranan da'i dalam mengatasi problem dakwah kontemporer, dalam penelitian ini disimpulkan bahwa tantangan dakwah tidak akan pernah selesai dan akan semakin bermacam seiring dengan perkembangan zaman dan berjalannya waktu, menurutnya dakwah yang baik adalah bukan hanya memberikan sebatas keinginan masyarakat tapi lebih pada bagaimana dakwah itu sendiri menjadi kebutuhan bagi masyarakat, maka dari sini sangat dibutuhkan khazanah yang objektif terhadap kondisi masyarakat. Seorang da'i juga harus benar-benar mampu menentukan skala prioritas pada proses dakwahnya antara mengembangkan potensi atau mengakomodasi permasalahan yang muncul pada fenomena tertentu sehingga proses dakwah benar-benar terlaksana dan berhasil secara maksimal (Ghozali: 2017, 305-306).

Berikutnya penelitian yang dillakukan oleh Agus Salim (2017) tentang peran dan fungsi da'i dalam perspektif psikologi dakwah, pada penelitian ini dihasilkan kesimpulan bahwa dalam perspektif psikologi, seorang da'i benarbenar harus mengetahui kondisi mental dan psikologis mad'u sebelum memulai proses dakwahnya agar hasil yang dihasilkan setelahnya benar-benar sesuai 
dengan tujuan dilakukannya dakwah tersebut. Hal ini juga selaras dengan tujuan dakwah dimana seorang da'i sangat memahami perannya secara psikologis dan tugasnya untuk 'mempengaruhi' mad'u agar mengikuti goal dari proses dakwahnya (Salim: 2017, 106).

Penelitian yang dilakukan oleh Ahmad Syahid (2018) tentang Peran da’i dalam menjaga kelestarian alam. Pada penelitian ini ditarik garis intisari bahwa peran da’i dalam menjaga kelestarian alam dan lingkungan hidup sebagai nikmat, karunia dan ciptaan Allah juga merupakan salah satu bentuk dakwah keislaman, hal tersebut juga selaras dengan tugas manusia dimuka bumi sebagai khalifah yang bermakna menjaga juga dapat berarti pada menjaga lingkungan agar tetap indah. Hal ini juga termasuk sebagai bentuk mengamalkan perintah Allah sebagai pencipta semesta alam yang mana juga dimulai dari rumah-rumah kaum muslimin, masjid dan tempat-tempat strategis kaum muslimin yang lain (Syahid: 2018, 36).

Yang menjadi pembeda antara penelitian ini dengan penelitian di atas adalah objeknya lebih spesifik pada da'i dari kalangan Nahdlatul Ulama' dan pembahasan dalam penelitian ini lebih berfokus pada nasehat dan dawuh para da'i Nahdlatul Ulama dalam upaya pencegahan Covid-19, sedangkan pada penelitian di atas lebih berfokus pada hal-hal lain seperti masalah Islam kontemporer, kelestarian alam dan posisi peran da'i dalam perspektif psikologi dakwah, sehingga terlihat terang perbedaannya antara penelitian di atas dengan artikel ini. Penelitian ini diharapkan dapat menjadi salah satu upaya untuk memutus dan mencegah rantai penyebaran Covid-19 di masyarakat dalam aspek dakwah.

Karena kajian ini dilakukan untuk mengungkapkan dan menela'ah pesanpesan da'i NU tentang pencegahan dan penanganan Covid-19, maka kajian ini menggunakan pendekatan analisis konten dimana akan membahas secara mendalam dan menggali informasi dari data tersaji, uraian akan dilakukan secara sistematik dan objektif. Subjek dari pembahasan ini ada Gus Mus, Gus Miftah dan Gus Baha dan sumber primer dari penelitian ini adalah video ceramah dan nasehat para da'i berikut yang terdapat di Youtube tentang penanganan dan pencegahan Covid-19. Setelah proses coding hasil analisis maka akan dihasilkan perbedaan dari masing-masing video. Sedang analisis isi data penelitian ini akan menjelaskan pesan dakwah para da'i tersebut terkait Covid-19.

Penelitian ini menggunakan dasar pemikiran Uses and Gratification Theory atau dikenal dengan teori kegunaan dan kepuasan. Dengan dasar bahwa pandemi Covid-19 menjadikan masyarakat benar-benar membutuhkan informasi baik secara medis maupun ruhaniah yang kemudian lahirlah sebuah motif sehingga peniliti memiliki sudut pandang bahwa penggunaan teori ini memiliki 
loyalitas pengaruh yang sangat besar dalam kajian ini. teori ini memiliki dasar yang sesuai dan kuat untuk digunakan sebagai teknik dalam penelitian ini.

Teori yang pertama kali digagas oleh Herbert Blummer dan Elihu Katz ini berpandangan bahwa khalayak atau audien sebagai pemakai media berperan aktif dalam memilih dan menggunakan media mana yang hendak ia konsumsi dan jadikan bahan menambah wawasan atau sejenisnya. Maka dari sini dapat digambarkan bahwa komunikan atau pengguna media tersebut juga memiliki peran aktif dalam proses komunikasi. Secara harfiah komunikan juga memiliki kendali terhadap media mana yang menurutnya paling baik dan sesuai untuk ia jadikan sebagai pemenuh kebutuhannya.

Karena khalayak memiliki control terhadap media yang hendak ia konsumsi dan gunakan, maka kecenderungannya akan menjadikan ia memilih apa yang dianggap penting dan sebaliknya mengabaikan hal yang menurutnya tidak sesuai kebutuhannya. Maka dari itu kecenderungan inilah yang mendorong adanya motif guna menggiring individu pada selektivitas konsumsi media. Karena ini dari teori ini adalah motif audien dalam menggunakan media, khususnya pada media massa. Maka lahir anggapan bahwa media massa tidak sepenuhnya memiliki kekuatan untuk mempengaruhi khalayak secara masif. Karena jika motif pada audien sudah terpenuhi maka hal tersebut juga sejalan dengan terpenuhinya kebutuhan audien tersebut. Maka jika media dapat memenuhi kebutuhan tersebut, efektiflah media tersebut terhadap khalayak.

Selanjutnya, dari berbagai penjelasan diatas dapat disimpulkan bahwa pendekatan uses and gratification mampu memetakan fokus penelitian dari fungsi komunikasi dalam perspektif media terhadap fungsi komunikasi dalam perspektif khalayak, yang mana dalam hal ini adalah masyarakat yang membutuhkan berbagai informasi tentang Covid-19.

\section{HASIL DAN PEMBAHASAN}

Perkembangan zaman dan ilmu pengetahuan adalah bentuk perkembangan dari manusia itu sendiri, akan tetapi dari tiap perkembangan tersebut selalu akan ada nilai atau sudut pandang tentang suatu hal juga bisa saja berubah. Termasuk didalamnya bisa lahir problem-problem baru yang harus dicarikan jalan keluar sebagai solusinya. Proses perkembangan ini juga berpengaruh pada sudut pandang dan nilai masyarakat tentang dakwah (Aziz: 2017, 5), namun sekali lagi, posisi Islam sebagai rahmatan lil 'alamin menjadikannya dapat menyesuaikan dengan perkembangan tersebut tanpa mengurangi atau membuang normanorma yang sebelumnya berlaku. Pada kasus Covid-19, fleksibelitas dakwah dibutuhkan agar tetap dapat menjangkau audien yang sudah dibatasi jarak interaksi akibat social distancing, sehingga peran da'i dalam di era yang 'luas' ini 
juga harus meluas pada berbagai aspek, salah satunya adalah menggunakan platform online sebagai media dalam menyebarkan syiarnya, sehingga jangkauan yang semua dibatasi akibat diminimalisirnya interaksi akibat Covid-19 ini dapat ter-cover dengan media online yang bisa di akses person by person lewat gadget yang dimiliki masyarakat sebagai mitra dakwah.

Karena fokus dari penelitian ini adalah video dari da'i Nahdlatul Ulama yang dimuat di Youtube, maka perlu dijelaskan bahwa video merupakan bentuk komunikasi massa. Jika bersandar pada objek yang bersifat heterogen, maka video yang disebar luas melalui televisi maupun internet merupakan bagian dari media massa, toh kalau mau beranggapan lebih, bahkan video adalah jantung dari kegiatan media massa itu sendiri, hal ini sejalan dengan semakin mudahnya video diakses oleh masyarakat secara umum sebagai audience yang dituju. Perkembangan industri video juga berdampak pada karakter sosial dan kultural masyarakat indonesia, yang mana hal ini disadari pada orde baru lalu, sehingga mulai saat itupun mulai dilakukan penyaringan atau gate keepering sebelum video tersebut menjadi konsumsi luas masyarakat (Ghazali and Fauzi: 2015, 16).

\section{Gambaran Umum Tentang Da'i Nahdlatul Ulama}

Nahdlatul Ulama atau yang dikenal dengan NU merukan organisasi yang berdiri di Surabaya pada 31 Januari 1926 M./16 Rajab 1344 H. organisasi ini dipelopori KH. Hasyim Asy'ari seorang ulama berdarah Jombang, dengan dasar untuk mempertahankan ajaran ahlus sunnah wal jama'ah (aswaja) di Indonesia setelah pada tahun 1924 M. paham sunni di Makkah ditaklukkan oleh Abdul Aziz bin Saud dan berganti dengan paham wahabi. Untuk lebih dalam mengerti tentang NU, tidak cukup jika hanya melihat pada latar sudut formal saat ia lahir, karena jauh sebelum organisasi ini lahir dalam bentuk jam'iyyah, NU sebelumnya masih berwujud jama'ah (community) yang berdasar pada aktivitas sosial keagamaan berkarakter khusus. Ajaran aswaja yang diterapkan NU ini bersumber dari AlQuran, Hadist, Ijma’ Ulama, dan Qiyas (Muhaemin: 2013, 315).

Sejak mulai dirintis, NU sepak terjangan organisasi ini dalam banyak sector khususnya perkembangan Islam di Indonesia sangatlah signifikan berpengaruh besar, berakar dari berbagai Lembaga pendidikan seperti pesantren, madrasah, majelis taklim, diniyah, dan perguruan tinggi Islam, NU sudah menjadi salah satu lokomotif besar Pendidikan di Indonesia. Peranan lainnya pada kemerderkaan Indonesia pula, masyarakat NU mulai dari kalangan kiai, santri dan masyarakatnyapun tercatat pernah ikut serta memperjuangkan kemerdekaan dari para penjajah. Hingga saat inipun, para ulama-ulama NU tak ayal selalu menjadi imam dalam menetukan jalan keluar permasalahan masyarakat baik secara sosial maupun keagamaan. Mulai dari para ulama-ulama besar NU, hingga tokoh-tokoh muda yang banyak pula menjadi sosok yang sangat berpengaruh dan dihormati 
oleh masyarakat (Kholiq: 2019, 138).

Dalam kurun waktu 3-4 tahun belakangan ini, ulama dan da’i muda NU mulai banyak 'tumbuh', dikenal dan mengambil peran dikalangan masyarakat sebagai sosok yang tabligh, yakni menyampaikan dan mengajarkan tentang keislaman pada masyarakat. Pada bahasan peran da'i dalam mencegah penyebaran Covid-19 pada kajian ini, penulis akan membatasi sumber tokoh NU sebagai sosok da'i pada 3 orang yakni Gus Mus, Gus Miftah dan Gus Baha agar fokus lebih terarah dan hasil yang diharapkan pada tulisan ini benar-benar sesuai dengan fokus yang ditentukan.

KH. Mustofa Bisri, atau lebih akrab disapa Gus Mus merupakan salah satu tokoh ulama senior NU, terkenal dengan konsep dakwah multikultural serta pendidikan keislaman. Hampir dalam setiap proses dakwahnya entah itu ceramah, pengaiian, seminar dan lain semacamnya, Gus Mus selalu menggunakan konsep konstruktif dan kondusif dalam hubungan iman antar umat beragama. (Samsuriyanto, 2018: 14) Selain metode dakwah pada umumnya, Gus Mus juga melakukan pendekatan dakwah melalui karya-karya sastra dan ilmiah yang ia tulis sebagai sarana untuk berdakwah.

Berbeda dengan KH. Miftah Maulana Habiburrahman atau biasa dikenal dnegan Gus Miftah, tokoh da’i NU yang satu ini mulai ramai dikenal sejak salah satu video dakwah ceramahnya di diskotik tersebar dan viral di berbagai media, sehingga Gus Miftah dikenal dengan da'i klub malam. Meski terkesan cukup nyentrik namun perlahan tapi pasti, dakwah Gus Miftah mulai banyak menarik mad'unya untuk bertaubat bahkan ada tokoh-tokoh publik dan artis tanah air yang memeluk agama Islam seperti DJ Katty Butterfly dan Deddy Corbuzier (Kosmawijaya: 2019, 95).

Berikutnya adalah Gus Baha atau KH. Ahmad Bahauddin Nursalim, Kiai asal Rembang yang sekaligus da'i yang cukup terkenal di media massa ini memiliki karakter yang khas dalam menyampaikan dakwahnya. Gaya dakwah Gus Baha terkenal sopan, santun dan penuh guyonan dengan tanpa mengurangi kuantitas dan kualitas materi yang disampaikan. Latar belakang beliau sebagai seorang hafizh, dewan tafsir, tim lajnah mushaf UII dan pengasuh salah satu pondok pesantren di Rembang memang menjadi bukti dari kealiman beliau sendiri (Pratama, 2020: 40).

\section{Analisis Pesan Dakwah Da'i dalam Mengatasi dan Mencegah Covid-19}

Pertama Gus Mus. Analisis pesan dakwah Gus Mus bertumpu pada 2 video beliau tentang Covid-19 yang beredar di Youtube, dalam hal ini peneliti menggunakan teknis analisis pesan pada video-video berikut: 
Tabel 1

Pesan Dakwah Gus Mus

\begin{tabular}{lll}
\hline No & Judul Video & Channel \\
\hline 1 & $\begin{array}{l}\text { Dakwah Gus Mus dalam Menyikapi Corona (Covid- } \\
\text { 19) }\end{array}$ & NU Update \\
2 & $\begin{array}{l}\text { Gus Mus: Dokter NU Waktunya Berdakwah Tentang } \\
\text { Kesehatan }\end{array}$ & Gus Mus Channel \\
\hline
\end{tabular}

Sumber: Observasi penulis 2021

Salah satu sifat dakwah adalah mempermudah dan bukan menyulitkan. Hal ini sesuai dengan landasan Islam sendiri sebagai agama yang Allah inginkan kemudahan bagi hambaNya, sebagaimana dalam satu contoh, Allah memberi keringanan berpuasa pada orang yang sedang safar atau sakit (Asy-Syaukani: 2018, 707).

Dalam video berjudul "Dakwah Gus Mus dalam Menyikapi Corona (Covid-19)" yang diunggah oleh channel NU Update, beliau menjelaskan bahwa Islam adalah agama kemudahan dimana didalamnya Allah tidak menghendaki kesukaran sesuai dengan firmannya:

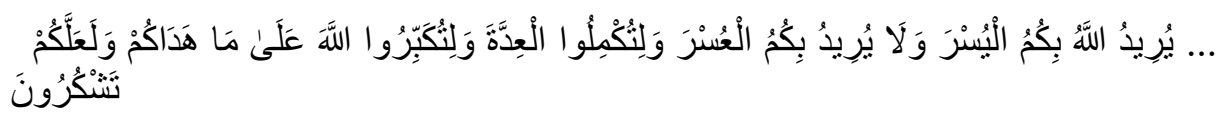

"...Allah menghendaki kemudahan bagimu, dan tidak menghendaki kesukaran bagimu. Dan hendaklab kamu mencukupkan bilangannya dan hendaklab kamu mengagungkan Allab atas petunjuk-Nya yang diberikan kepadamu, supaya kamu bersyukur." (QS. Al-Baqarah: 185)

Tuhan tidak menjadikan dalam agama Islam ini kesulitan untuk penganutnya, dibuktikan dengan hadist Nabi sebagai pembawa risalah keislaman:

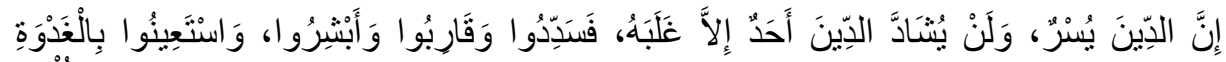

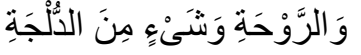

"Sesunggubnya agama itu mudah, dan sekali-kali tidaklah seseorang memperberat agama melainkan akan dikalabkan, dan (dalam beramal) hendaklah pertengahan (yaitu tidak melebibi dan tidak mengurangi), bergembiralah kalian, serta mohonlah pertolongan (didalam ketaatan kepada Allab) dengan amal-amal kalian pada wak.tu kalian bersemangat dan giat”. (HR. Bukhari 39, An-Nasai 5034)

"inna-d diina yusraa", bukan addinu yusra, yakni terdapat penekanan pada lafal 'Inna' yang berarti sungguh, hal ini bermakna bahwa Nabi pun benar-benar 
menyatakan bahwa Islam adalah agama yang diturunkan dengan banyak kemudahan didalamnya. Jadi premisnya adalah jika ada seorang muslim yang justru memberatkan syariat Islam, itu berarti bahwa dia menghendaki kewalahan atas dirinya sendiri. Kemudahan dalam beragama ini sejalan dengan sabda Rasulullah

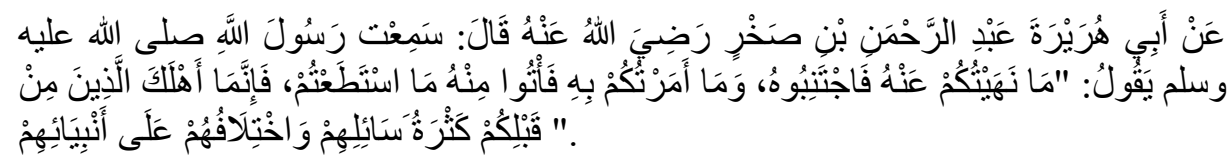

Dari Abu Huroirob Abdur Rohman bin Shokbrin Rodhiyallabu anbu ia berkata "Saya telah mendengar Rosulullah Shollallahu alaibi wa sallam bersabda: "Apa apa yang saya larang darimu maka jaubilah, dan apa apa yang saya perintabkan, maka lakukanlah semampumu, sesunggubnya yang membinasakan manusia sebelum kamu adalah banyak pertanyaan dan perselisiban mereka terhadap para Nabinya " (HR Bukhori dan Muslim)

'Mastata'tum' yang bermakna semampumu terhadap bentuk-bentuk seruan dan perintah Nabi adalah gambaran dari kemudahan itu sendiri, Allah juga berfirman "ittaqullaha mas-tatha'tum". Contohnya, dalam kondisi normal seorang muslim diperintahkan untuk shalat dzuhur dan ashaar sebanyak 4 rakaat, namun jika dalam keadaan udzur seperti safar maka ada keringanan untuk menunaikan shalat tersebut menjadi 2 rakaat (qashar), bahkan pada kasus khusus lainnya diperbolehkan gabung (jama'). Dari banyak bentuk kemudahan ini, terdapat kesimpulan bahwa agama Islam ini memang Allah turunkan untuk kebutuhan dan sesuai kondisi hamba-Nya, kasus lain yang Gus Mus contohkan adalah keringanan mengganti puasa Ramadhan saat melakukan perjalanan jauh dan rukhsah shalat jum'at jika terjadi badai atau hujan lebat.

Menurut Gus Mus, kasus pandemi Covid-19 ini juga menjadi bentuk musibah yang melahirkan udzhur tertentu bagi kaum muslimin untuk tidak melakukan ritual ibadah sama seperti hari-hari biasa, misal shalat sunnah dan berjamaah di masjid, silaturrahmi dengan saudara dan teman, pengajian dan tabligh akbar serta berbagai bentuk ritual ibadah yang melibatkan kerumunan (jama'ah), sebab dikhawatirkan melahirkan mudharat yang lebih besar daripada manfaatnya seperti menjadi kluster-kluster baru yang menyebarkan virus dan menjadikan wabah ini semakin sulit dikendalikan. Sebagai bentuk pengganti dari ibadah-ibadah sunnah yang hanya bisa dilakukan di Masjid, Gus Mus memberikan pemahaman bahwa pahala ibadah-ibadah tersebut masih bisa kita raih dengan memperbanyak shalat sunnah yang lain seperti dhuha, qabliyah dan ba'diyah, berdzikir ditengah kesendirian akibat terbatasnya interaksi dengan sesama, Rasulullah bersabda "Kullu sullamah minan-naas: setiap persendirian kita bisa menjadi ibadah". Terbatasnya interaksi seperti isolasi mandiri dan sejenisnya 
oleh Gus Mus disarankan agar diisi dengan amal-amal baik seperti berdzikir, bershalawat dan beristigfar. Memperbanyak istigfar juga dapat menjadi penolak bala' di masa seperti saat ini, sebab Allah tidak akan mengazab suatu kaum selama ada Rasulullah di tengah-tengah kaum tersebut dan Allah juga tidak akan menyiksa suatu kaum selagi kaum tersbut masih beristigfar, dengan bershalawat kita juga dapat mengharap kehadiran Rasulullah di tengah-tengah kita juga diiringi dengan istigfar.

Dalam satu video Gus Mus saat mengisi tausyiah online dalam rangka memperingati harlah ke-2 Perhimpunan Dokter Nahdlatul Ulama' yang diunggah di channel Youtube 'Gus Mus Channel', beliau memberikan sambutan dan nesehat diantaranya sebagai rasa syukur seorang dokter yang memiliki tanggung jawab kemanusiaan khususnya dokter dengan latar NU yang tidak hanya dituntut pengabdian medis melainkan juga dalam lingkup dakwah yang mampu memberikan manfaat pada masyarakat secara umum, terlebih lagi masa pandemi seperti saat ini memang seharusnya menjadi wadah yang sangat pas bagi seorang dokter untuk berdakwah dan sekaligus mengabdi sebagai garda terdepan dalam penanganan Covid-19, dimana sebagai tenaga ahli, para dokter berhak untuk mendakwahi para tokoh yang masih mengira bahwa wabah ini adalah rekayasa atau hal abal-abal sehingga dapat bersama-sama mengambil peran dalam menuntaskan permasalah wabah ini. Gus Mus juga menjelaskan bahwa dalam hal medis seyogyanya memang harus percaya kepada dokter, sebab dokterlah yang ahli di bidang tersebut. Meninggal akibat virus ini memanglah takdir, tapi jika sepenuhnya berpandangan seperti berikut berarti menyerah dan tidak paham hifdu-n nafsi (khusunya orang NU) menurut Gus Mus, sebab sebelum berpasrah diri sebagai orang NU semestinya sudah tau dan paham mengenai kewajiban ikhtiar sebab dalam hadist "jika suatu hal tidak dipasrahkan pada ahlinya, maka tunggulah tanggal mainnya". Pada akhir video Gus Mus berpesan "yang bisa apa-apa, lakukanlah apa-apa, (bagi) yang tidak bisa apa-apa, cukuplah berdoa".

Kedua Gus Miftah. Allah menyuruh setiap hambaNya untuk bertawakal dalam setiap keadaaan, karena dengannya membuktikan bahwa tidak hal yang dapat terjadi atau dilakukan selain dengan kehendak dan taufik Allah (Basri, 2008: 33). Sama halnya dengan Covid-19 ini, sebagai muslim yang baik haruslah mengedapankan iman dan tawakkal lebih dahulu disamping tetap melakukan ikhtiar dalam menanganinya.

Dalam menyikapi suatu fenomena, da’i haruslah bersikap aktual dan beradaptasi dengan masalah dan kebutuhan mitranya. Dalam artian bahwa dakwah yang mereka lakukan haruslah sesuai dan mencoba membangun sikap dan perilaku aktif dalam menyikapi permasalahan yang sedang terjadi, tentunya diperlukan perilaku dan pengalaman agama dari da’i tersebut. Model dakwah ini 
Moh. Lukman Hakim dan Moh. Ali Aziz

disebut dakwah Islam aktual-transformatif (Fahrurrozi, 2017: 44).

Fokus objek yang menjadi sumber dari ceramah atau nasehat Gus Miftah berfokus pada 3 video beliau yang membahas tentang Covid-19. Sebagai bahasan bahwa Gus Miftah juga mengambil peran dalam mengedukasi masyakarat dalam mencegah penyebaran virus ini.

Tebel 2

Pesan Dakwah Gus Miftah

\begin{tabular}{|c|c|c|}
\hline No & Judul Video & Channel \\
\hline 1 & $\begin{array}{l}\text { Buka-Bukaan Dengan Gus Miftah Soal Covid-19 } \\
\text { Hingga Kehidupan Cinta di Lokalisasi Sarkem | Free } \\
\text { Talk }\end{array}$ & Talk Show tvOne \\
\hline 2 & $\begin{array}{l}\text { Tanggapan Gus Miftah Tentang Wabah Virus } \\
\text { Corona }\end{array}$ & Gus Miftah Official \\
\hline 3 & Mengambil Hikmah Covid-19 bersama Gus Miftah & Radar Jogja Channel \\
\hline
\end{tabular}

Sumber: Observasi penulis 2021

Dalam salah satu sesi talk show bernama FreeTalk di tvOne, Gus Miftah diundang untuk berbincang-bincang mengenai Covid-19 dan kegiatan dakwahnya di lokalisasi. Menurutnya, ibarat sebuah pelayaran, masa pandemi seperti saat ini adalah sebuah ombak sedang keimanan kita adalah kapalnya, maka bukan sebenarnya bukan ombaknya terlalu besar melainkan kapal kita yang seharusnya lebih kita besarkan agar siap menghadapi berbagai macam jenis badai dan ombak, pesan ini juga pernah Gus Miftah sampaikan via daring di sesi Mata Najwa yang di tayangkan di Trans7. Wujud keimanan yang dimaksud disini bukan semerta-merta yakin bahwa segala penyakit dan kematian itu datangnya dari Allah namun tidak ikhtiar menjaga diri, hal ini juga tidak tepat menurut Gus Miftah. Sebagai hamba Allah kita tidak boleh ketakutan dengan Covid-19, namun juga tidak meremehkan wabah ini dengan dalih 'iman'. Pada akhir sesi talk show ini, Gus Miftah mengatakan "boleh saja saat ini bumi sedang lockdown, tapi pintu langit tidak pernah lockdown", statement ini bermakna bahwa seberat apapun situasi yang diakibatkan pandemi ini, ingatlah bahwa kita masih memiliki Allah yang akan selalu melimpahkan kasih sayangNya dan melindungi kita semua sekuat apapun kita berikhtiar.

Pada vlog berjudul "Tanggapan Gus Miftah Tentang Wabah Virus Corona" yang diunggah di channel pribadi Gus Miftah, pada video tersebut Gus Miftah tampak berada dalam pesawat dalam rangka menghadiri salah satu undangan dakwah, seolah menjawab pertanyaan "Kenapa Gus Miftah masih menghendaki hadir pengajian? Gak takut Corona?" beliau menjelaskan bahwa 
keberangkatannya tersebut dalam rangka menghormati pihak panitia yang tetap melanjutkan agenda kajiannya. Selanjutnya beliau menjelaskan bahwa sikap yang tepat untuk menyikapi wabah pandemi ini adalah tidak takut berlebihan, tidak panik dan tetap waspada, dalam artian tetap menjaga dan mematuhi protokol Kesehatan Covid-19. Mengutip firman Allah dalam Al-Quran:

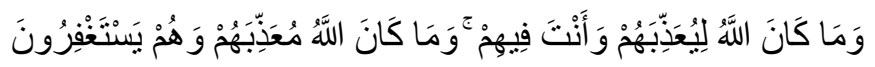

"Dan Allah sekali-kali tidak akan mengazab mereka, sedang kamu berada di antara mereka. Dan tidaklah (pula) Allah akan mengazab mereka, sedang mereka meminta ampun”. (QS. Al-Anfal: 33)

Melalui ayat tersebut, Gus Miftah menghimbau untuk tetap menghadirkan Rasulullah dalam setiap perilaku dan sikap kita, mulai dari memperbanyak shalawat, menjaga istigfar dan melaksanakan sunnah-sunnahnya maka in syaa Allah kaum muslimin akan selamat dan dilindungi dari adzab, marabahaya dan musibah oleh Allah SWT.

Berikutnya di video berjudul "Mengambil Hikmah Covid-19 bersama Gus Miftah" yang diunggah oleh Radar Jogja Channel menjelaskan bahwa agenda kajiannya yang semula dalam sehari bisa sampai 3 kali pengajian banyak beliau cancel demi menjaga kemaslahan dan menghidari kemudharatan Covid-19, sebab penularan Covid yang memang sangat transparent dan sulit terdeteksi, dalam artian siapa saja bisa tertular tanpa diketahui dan disadari. Karena bisa saja seseorang sudah terpapar namun kondisi jasmaninya sedang baik, dia akan terlihat sehat seperti biasa namun tetap bisa menularkan kepada orang lain. Jadi Gus Miftah memberikan saran untuk tetap berdiam dirumah saja dan mengurangi interaksi sosial dengan lingkungan untuk sementara waktu.

Lantas bagaimana menyikapi kebosanan yang datang ketika berdiam di rumah saja, pada video tersebut Gus Miftah menjelaskan bahwa dirinya tetap mengisi waktu luang di rumah tersebut dengan mengaji atau kajian yang dia lakukan via online bersama jama'ahnya. Menurut Gus Miftah selain quality time bersama keluarga menjadi semakin banyak, waktu dengan jama'ah pun tetap terjaga dengan dialihkannya kajian beliau menjadi online, meski secara suasana tetap akan ada perbedaan. Sebagai bentuk antisipasi, Gus Miftah juga melarang para santrinya untuk keluar dari lingkungan pondok Ora Aji yang diasuhnya dan membatasi orang luar pondok tersebut untuk keluar masuk lingkungan pondoknya.

Gus Miftah mengajak pada jama'ah untuk Bersama menyadari bahwa Corona ini merupakan salah satu bukti kebesaran Allah dan kelak Allah pula yang akan mendatangkan obat dan penawar dari virus ini. dipertangahan video ini Gus Miftah berkata "Berdoalah kepada Tuhannya Corona (Allah), supaya 
Moh. Lukman Hakim dan Moh. Ali Aziz

Corona segera dihilangkan. Jangan sampai gara-gara Corona kita kehilangan Tuhan".

Ketiga Gus Baha. Secara umum, menurut Al-Quran, dakwah memiliki 3 metode, diantaranya adalah: hikmah, mau'idah hasanah dan mujadalah bil-lati hiya ahsan. Mau'idah hasanah adalah metode dimana da'i memberikan nasehat mengingatkan atau pembelajaran yang baik kepada mad'unya. Dengan cara berikut diharapkan mitra dakwah dapat merespon dan menerima proses dakwah tersebut dengan tulus (Taufik: 2013, 93-94). Dari berbagai ceramah dan kajiannya, Gus Baha cenderung banyak menggunakan metode ini dalam dakwahnya, hal ini juga sejalan dengan ke'aliman beliau sebagai kiai.

Secara spesifik, Gus Baha tidak banyak membahas tentang Covid-19 secara langsung di berbagai ceramah ataupun kajiannya. Namun, terdapat beberapa video kajian beliau yang didalamnya meruju' pada sikap pencegahan dan penanganan Covid-19 ini.

Tabel 3

Pesan Dakwah Gus Baha

\begin{tabular}{lll}
\hline No & Judul Video & Channel \\
\hline 1 & $\begin{array}{l}\text { Gus Baha - Kalau Sakit, Saya Takut Ibadah Saya } \\
\text { Berkurang }\end{array}$ & NU Online \\
2 & Tidak ada penyakit yang menular - Ngaji Gus Baha & KALAM - Kajian Islam \\
\hline
\end{tabular}

Sumber: Observasi penulis 2021

Dalam video berjudul "Gus Baha Kalau Sakit, Saya Takut Ibadah Saya Berkurang" yang diunggah oleh Youtube Channel NU Online, Gus Baha menyampaikan bahwa kita tidak boleh takut terhadap kematian, karena setiap orang sudah memiliki garis takdir tentang ajal dan kematiannya masing-masing, pun juga dengan Covid yang dapat mengakibatkan kematian. Sebagai mana dulu Ali bin Abi Thalib tetap melaksanakan shalatnya dengan khusyuk meskipun tengah diintai musuh.

Dalam Tafsir Kasyf al-Asrar Maibadi dijelaskan: Pada satu waktu ada suatu anak panah yang menembus kaki Khalifah Ali bin Abi Thalib, anak panah tersebut menancap dalam hingga mengenai tulangnya sehingga sulit untuk dicabut dan satu-satunya cara untuk mencabutnya adalah dengan menusukkan panah tesebut hingga tembus kemudian mematahkan ujungnya. Sang Khalifah meminta agar panah tersebut dicabut ketika ia shalat Ashar, dan benar saja ketika Ali sedang shalat dicabutlah panah tersebut dan ia tidak merasa kesakitan sama sekali sebab khusyuk beliau melaksanakan shalat, tidak ada rasa takut Ali bin Abi Thalib ketika ia berada dalam kenikmatan menyembah dan menghamba kepada 


\section{Allah SWT.}

Tidak takut yang dimaksud Gus Baha disini bukan berarti lepas begitu saja keluar rumah dan bebas beraktivitas sosial seperti biasanya, namun Gus Baha menjelaskan untuk tetap melakukan ikhtiar seperti menggunakan masker. Menggunakan masker disini pun jangan sampai diniati karena takut akan terhadap Corona secara mutlak, namun jika tetap ada rasa takut akan tertular virus Covid-19 ini, Gus Baha menyampaikan agar tetap menjaga niat dalam poros yang baik seperti takut akan berkurangnya ibadah amaliyah dan dapat merepotkan orang lain jika sampai tertular virus, oleh karenanya kita harus menjaga diri dan melaksanakan protokol kesehatan demi menjaga diri dari tertular dan menularkan Covid-19.

Pada video berjudul "Tidak ada penyakit yang menular - Ngaji Gus Baha” yang diunggah oleh Youtube channel KALAM - Kajian Islam, Gus Baha menjelaskan Sebagai hamba Allah yang beriman, seorang mukmin haruslah mendahulukan keimanan pada Tuhannya diatas segalanya, sehingga ia akan tetap berada dalam poros ketaatan dan terhindar dari jalur kesyirikan, secara sederhana mungkin hal ini bisa digambarkan dengan pemikiran bahwa Allah-lah pencipta segala sesuatu di alam semesta ini. dalam satu riwayat Rasulullah pernah mengatakan bahwa 'tidak ada penyakit yang menular' di depan khalayak. Kemudian orang-orang Yahudi yang ingin mempermalukan Nabi menyanggah Nabi begitu saja dengan memberikan contoh bahwa jika 1 unta yang terkena kudis jika dikumpulkan dengan unta yang lain, maka akan menularkan kudisnya pada unta yang lain. Dengan contoh tersebut orang Yahudi tersebut kemudian berkata kepada Nabi Muhammad "Wahai Muhammad, kata kamu tidak ada penyakit yang menular, lantas bagaimana dengan unta yang saling menularkan kudis ini?" kemudian Rasulullah menjawab "Jika memang penyakit ini menular, lantas siapa yang menularkan kudis ini pada unta pertama?”, mendengar jawaban Nabi, orang Yahudi tersebut tidak melanjutkan perdebatannya sehingga Rasulullah menjelaskan bahwa yang dimaksud beliau adalah penyakit memang diciptakan oleh Allah SWT.

Dari riwayat di atas, dapat disimpulkan bahwa memang berbagai macam penyakit apapun memang pada dasarnya diciptakan oleh Allah, entah itu sebagai peringatan, cobaan atau bahkan adzab yang diturunkan. Namun poinnya disini adalah sebagai seorang mukmin, sebelum memulai segala usaha untuk terhindar dari berbagai penyakit termasuk Covid-19 ini, iman bahwa penyakit ini diciptakan oleh Allah harus lebih dulu ditanamkan. Sehingga ikhtiar memang dilakukan atas dasar memohon perlindungan dari Allah Kembali dan bukan semata-mata hanya untuk menghindari penyakit. Sebab jika memang Allah sudah berkehendak pada suatu hal, sejauh dan sedalam apapun manusia berusaha untuk 
menghindar, itu tidak akan pernah berhasil. Sebab ketentuan Allah bersifat mutlak untuk seluruh ummat manusia.

\section{PENUTUP}

Untuk menjawab tujuan dari penelitian ini, berpangku pada analisis dan pembahasana yang telah dilaksanakan, artikel ini menghasilkan: pertama, dakwah Gus Mus menjelaskan bahwa Islam merupakan agama yang Allah turunkan sebagai kemudahan bagi ummatnya, bahkan dalam berbagai aspek ibadahnya sehingga pada suatu keadaan tertentu, seorang mukmin dapat memperoleh rukhsah atau keringanan dalam beribadah karena dan lain hal. Menurut Gus Mus kondisi pandemi yang banyak menimbulkan keresahan di kalangan masyarakat ini merupakan satu fenomena khusus yang melahirkan keterbatasan dalam berbagai aspek ibadah, sehingga pada beberapa ritual ibadah seperti shalat berjama'ah di masjid, shalat jum'at, pengajian dan sejenisnya patut mendapatkan rukhsah untuk dilakukan atau diganti menjadi ibadah di rumah saja, dengan tujuan untuk memutus rantai penyebaran Covid-19 dan menjadikan mashlahat di kalangan kaum muslimin. Jadi hal seperti ini menurut Gus Mus adalah suatu rukhsah tersendiri dan bukanlah suatu kesalahan.

Kedua, Dalam beberapa kesempatan seperti talkshow, ceramah daring dan konten vlognya, Gus Miftah menjelaskan bahwa sebagai seorang mukmin kita tidak boleh terlalu takut dan khawatir serta juga tidak menganggap remeh Covid19, namun lebih pada waspada dan tetap menjaga diri sesuai protokol yang dianjurkan pemerintah dengan tetap beriman dan menjaga keterpautan hati dengan Allah agar selalu dijaga dalam kesehatan dan kebaikan-Nya. Gus Miftah juga menyarankan untuk selalu menghadirkan Rasullullah dalam setiap aktivitas kita dengan berdzikir, beristigfar dan bershalawat sehingga Allah akan tetap menjaga kita semua semua dari adzab dan musibah.

Ketiga, Gus Baha adalah sosok da'i yang sangat filosofis, dalam beberapa ceramah dakwahnya yang beredar di Youtube, beliau menerangkan bahwa kematian adalah takdir yang pasti bagi tiap insan manusia, sehingga sebagai orang yang beriman kita tidak boleh (terlalu) takut terhadap virus Covid-19 ini. Namun disamping itu juga beliau menjelaskan untuk tetap melaksanakan protokol kesehatan seperti menggunakan masker menjauhi zona yang terpapar virus tersebut. Namun yang ditekankan oleh Gus Baha disini lebih pada esensi bahwa setiap ikhtiar kita mematuhi protokol kesehatan bukan karena kita takut terhadap Covid-19, namun lebih pada niat baik misal jika sampai terpapar kita akan merepotkan orang lain atau kualitas dan kuantitas ibadah kita kepada Allah akan berkurang. 


\section{DAFTAR PUSTAKA}

Al-Qahthani, S.A.W. (1424) Al-Hikmatu Fii Da'wati Illa Allabita'ala. 4th ed. Riyadh: Maktab Malik Fahd Al-Wathani.

Asy-Syaukani, I. (2018) Tafsir Fathul Qadir Jilid 1. Pustaka Azzam.

Aziz, Moh. A. (2017) Ilmu Dakwah. 6th ed. Jakarta: KENCANA.

Basri, M. M. (2008) Indahnya Tawakkal. Edited by Raudina. Surakarta: Indiva Pustaka.

Bayanuni, M.A.F. 1995. Al-Madkhal Ila Ilmi Dakwah. 3rd ed. Beirut: Muassasah Ar-Risalah.

Fahrurrozi (2017) Model-Model Dakwah di Era Kontemporer. Edited by Subhan Abdullah Acim. 1st ed. Mataram: LP2M UIN Mataram.

Faiqah, F. (2016) "Youtube \{Sebagai\} \{Sarana\} \{Komunikasi\} \{Bagi\} \{Komunitas\} \{Makassarvidgram\}." Jurnal Komunikasi Kareba 5.

Ghazali, A. \& M.I.F. (2015) Ekonomi Kreatif: Rencana Pengembangan Video Nasional 2015-2019. PT. Republik Solusi.

Ghozali, M. I.K. (2017) "Peranan Da'i Dalam Mengatasi Problem Dakwah Kontemporer." Mawaizh 8. https://doi.org/https://doi.org/10.32923/ maw.v8i2.777.

Sainuddin, I.H. (2020) "Transformasi Dakwah di Masa Pandemi Covid-19." OSFPrefprint, 10.31219/osf.io/nakhy

Ihsanuddin (2020) Fakta Lengkap Kasus Pertama Virus Corona Di Indonesia diunduh dari Kompas.Com." pada March 2, 2020. https://nasional.kompas.com/read/2020/03/03/06314981/faktalengkap-kasus-pertama-virus-corona-di-indonesia?page $=$ all.

Juhari (2020) "Tantangan Dan Arah Dakwah Di Tengah Ancaman Pandemi Covid-19." Jurnal Peurawi 3.

Kholiq, A. (2019) "Kaderisasi Da'i Moderat Era Milenial Di Pengurus Cabang Nahdlatul Ulama Kabupaten Kendal." Jurnal An-Nida 11.

Kosmawijaya, T. (2019) "Da'i Diskotik: Dakwah Gus Miftah Di Tempat Hiburan Malam Yogyakarta.” UIN Sunan Ampel Surabaya.

Muhaemin (2013) "Teologi Aswaja Nahdlatul Ulama Di Era Modern: Studi Atas Pemikiran Kyai Hasyim Asy'ari.” Jurnal Diskursus Islam 1.

Munir, M., Fauzi, M. dan Putra, R.A (2020) "Pesan-Pesan Dakwah Da'i Pada Khalayak (Analisis Konten Pada Ceramah Da'i Tentang Covid-19 Di Youtube)." At-Tabsyir 7. http://journal.stainkudus.ac.id/index.php/ komunikasi.

Nurhuda, M. \& Al-Farisi, L. (2020) "Pesan Dakwah Dalam Lirik Lagu 'Kebaikan Tanpa Sekat." Anida (Aktualisasi Nuansa Ilmu Dakwab) 20.

Pratama, S. (2020) "Campur Kode Bahasa Arab Dalam Ceramah Gus Baha Pada Acara Maulidyah Dan Harlah Ke 52 PP. Al-Anwar, 06 Rabi’ul Awwal 
Moh. Lukman Hakim dan Moh. Ali Aziz

1440 H/14 November 2018." An-Nida' 3. https://ejurnal.darulfattah. ac.id/index.php/Annaba.

Salim, A. (2017) "Peran Dan Fungsi Da’i Dalam Perspektif Psikologi Dakwah." Al-Hikmah 09.

Samsuriyanto (2018) "Dakwah Moderat Dr. (HC) KH. Ahmad Mustofa Bisri Di Dunia Virtual.” UIN Sunan Ampel Surabaya.

Aji, R.H.S. (2020) "Dampak Covid-19 Pada Pendidikan Di Indonesia: Sekolah, Keterampilan Dan Proses Pembelajaran.” Salam Jurnal 7. https://doi.org/ 10.15408/sjsbs.v7i5.15314.

Syahid, A. (2018) "Peran Da'i Dalam Menjaga Kelestarian Alam." Mediakita 2: $27-37$.

Taufik, M. T. (2013). Dakwah Era Digital. Kuningan: Pustaka Al-Ikhlash. 